\title{
Rise of ineffective incentives: New empirical evidence on tax holidays in developing countries
}

\author{
Saila Naomi Stausholm \\ Copenhagen Business School, 2017
}

\begin{abstract}
Developing countries employ tax incentives in the hope of attracting investors, but questions remain on the effects of these policies. Asking whether tax incentives undermine or facilitate development, this paper investigates tax rates and tax holidays in terms of both economic and social impacts in developing countries 1985-2014 in the largest panel data set ever deployed for this purpose. The collection of new data results in three major contributions to the existing literature. First, the analysis shows that the use of tax holidays has increased over the last decade throughout all four regions surveyed: Latin America, Asia, Africa and the Caribbean. Second, the analysis finds that the effect of tax holidays on FDI is negligible and decreasing, and importantly, that it does not translate into neither real capital accumulation nor economic growth. Third, the paper then investigates how the revenue losses from tax incentives can mean real differences for human development by analyzing the effect on tax revenues, spending, health and education outcomes. The paper concludes that tax holidays are negatively correlated with tax revenues, and as revenues decrease, the spending on education decreases. This has real effects, as evidenced by a significant negative correlation with enrollment in primary education. The analysis concludes that tax holidays overall have more negative than positive impacts on sustainable development.
\end{abstract}

\section{Introduction}

A key issue in economic development is the attraction of investment. Investment, especially foreign direct investment, increases the capital to labor ratio and can create spillovers of technology and knowledge, all of which can be beneficial for productivity and growth. With the opening of capital markets, investments should theoretically be flowing into the markets where capital is not abundant. However, as well described by Lucas (1990), capital does not seem to go into developing countries; a phenomenon that is both theoretically puzzling and politically important. Popular theories explaining this focuses on the concept of the investment climate: how institutional, infrastructure and market "deficiencies" create too challenging conditions for businesses that are therefore not willing to take on the additional risks of investing. (Bolnick 2004; Forsgren 2008; Zolt 2015) Pursuing the goal of increasing investment, policy makers seek to alleviate 
these concerns by lowering the cost of investment. But facing the larger challenges of the investment climate is hard: infrastructure, institutions and markets do not change easily or quickly. Some countries have therefore followed the road of "compensating" for the larger challenges rather than overcoming them; particularly by offering investors incentives such as subsidies, land grants, special economic conditions or more favorable tax conditions. In an environment where many countries follow this road, this has led to an overall environment of tax competition, where countries under-bid each other in the quest for investment, and ultimately development. If the tax policies are not successful in attracting investment and growth however, the countries are risking the long term sustainability of public finances. Furthermore, even if they are somewhat effective, they might undermine public finances to such an extent that their overall impact on development is negative if they decrease the ability to invest in public services like education and health. This paper presents an empirical investigation into whether tax incentives are undermining or facilitating development.

This paper adds new data and findings to the debate on taxes and development, investment and growth. The paper first outlines the theoretical background for why tax incentives are used to attract investment in a development context. Section 3 will then show how previous literature has looked at effects of tax incentives. Section 4 outlines the methodology and data for this analysis, and section 5 reports the result of this new dataset in terms of findings on the development of tax policies as well as regressions on the effect of tax policies on economic and development outcomes. Focusing specifically on tax holidays, it is shown through a large panel data set that the use of tax holidays have increased in the last decade across the developing world. It is then shown that the effects of tax holidays on economic variables are uncertain at best and negative at worst, especially when public finances and effect on welfare investments such as school enrollment is taken into account. Section 6 concludes on the findings and point to possible policy paths for the future.

\section{Tax incentives for investment}

Tax incentives are measures that provide a favorable tax treatment to companies given some criteria such as investment, and may be targeted at favoring certain regions, activities or industries. (A. Klemm and Parys 2011; Zee, Stotsky, and Ley 2002; Tuomi 2012)

The simplest form of tax policy incentivizing investment is to simply lower the corporate income tax rate. This is easy to administer as well as transparent. However, the benefits go disproportionately more to firms that are already highly profitable. Furthermore, it is hard to discriminate between new and incremental investments and the existing investments. Tax holidays are similarly simple. They are policies in which investors are exempted from paying taxes for a fixed number of years, contingent upon criteria such as being a foreign investor, investing in certain industries and activities that are considered particularly important for growth. The policies can be obtained either through rules-based fixed criteria or by discretionary power from the public authori- 
ties. Other tax incentives include tax stability agreements, accelerated depreciation, tax credits, investment allowance and loss relief. This analysis will be on tax rates and tax holidays which are wide spread in developing countries. (Zee, Stotsky, and Ley 2002; M. A. Klemm, Botman, and Baqir 2008; A. Klemm and Parys 2011; Tuomi 2012)

The idea behind tax incentives in the specific context of developing countries is that they can compensate for other deficiencies in the investment climate. Theoretically, a tax incentive increases the expected value of an investment. It can therefore be argued that if investors are rational and profit maximizing, then this will lead to more investment. (Wells et al. 2001; Margalioth 2003; Bolnick 2004) The theories behind lowering the cost of capital to increase investment lend some support to the rationale for developing countries to implement tax incentives. However, several aspects of tax holidays raise the question of whether or not they are beneficial in practice.

Tax policies can distort incentives in the economy and will be attracting different forms of investment projects. Since tax holidays limit the lower tax rate to a shorter period, they incentivize short term investments rather than long term compared to a permanent decrease int he tax rate.

Tax holidays risk having high redundancy rates, meaning they are applied to investments that would have taken place anyway. Tax incentives that work by lowering the rate or give complete exemption provide relatively larger benefits to the more profitable investments, which are exactly the kinds of investments that would be taken place even without the policy, making the incentives redundant. When incentives are aimed at discriminating foreign investment over domestic, domestic investors might become eligible by "round-tripping", ie. by setting up a foreign subsidiary and posing as a foreign investor. This furthermore increases the redundancy rate, as these investments would have happened either way. (Fletcher 2002; M. A. Klemm, Botman, and Baqir 2008; Johnson and Toledano 2013)

Furthermore, tax holidays risk attracting investment types that are relatively less beneficial for the economy in terms of spillover effects through backward linkages. Projects that are aimed at specific skills, resources or market characteristics are less responsive to tax policies than efficiency-seeking FDI projects, which are usually of the more footloose, export-oriented kind with fewer potential spillover effects. (Johnson and Toledano 2013) This undermines the effects of the policy such that even if FDI is attracted the country might not get all the gains usually associated with FDI.(Cantwell and Mudambi 2005; M. A. Klemm, Botman, and Baqir 2008; Tuomi 2012)

Tax holidays also create opportunities for abuse and tax avoidance. As companies are usually not audited during a tax holiday there are opportunities for tax avoidance by shifting profits from audited and taxed enterprises to the ones benefiting from the holiday through transfer pricing. Furthermore firms can prolong the exemption period by closing down an operation and starting it again under a different name as the tax holiday period ends. (Zee, Stotsky, and Ley 2002; Fletcher 2002)

It is also a risk that even if they are effective in attracting FDI, these investments crowd out domestic investment and therefore overall is not beneficial for growth. FDI crowding out domestic investment has previously been found to be a tendency in developing countries, particularly in Latin America. (Agosin and Machado 2005) This goes to 
the broader debate on the effects of FDI on development. (Alfaro and Chauvin 2016) Discussing the overall effects of FDI on development is beyond the scope of this paper, but the analysis in this paper makes sure to measure the effect of tax policies more broadly than just FDI in order to capture the effects of development rather than just FDI.

Increasing the importance of evaluating the effects of tax incentives is the fact that these policies are potentially harmful for government revenues. Developing countries suffer from strained public finances - a resource constraint that, coupled with low private savings, is harming development, since there is a lack of investment in infrastructure and human capital. (Di John 2008; IMF 2011) Tax policies that are costly to public finances are therefore effectively prolonging developing countries' dependence on aid, if they fail to attract investment and spur growth. (Johnson and Toledano 2013)

Tax incentive policies can theoretically be positive for growth and development if they are actually working as intended and attract investment by lowering cost of capital. However, they pose large risks of skewed incentives, harmful abuses as well as risks to public finances. Tax incentive policies should therefore be evaluated in light of their actual effects on development - on FDI as well as broader indicators.

\section{The effectiveness of tax incentives: what we know}

The effects of tax policies on investment and growth is an ongoing important debate within economic research. While many papers find that lower taxes have positive impacts on macroeconomic variables (Lee and Gordon 2005; Bösenberg, Egger, and ZollerRydzek 2017), the debate persists as others find no long term effects (eg. Stokey and Rebelo (1995)) and there is substantial variation across studies in size of the effect. (Mooij and Ederveen 2003) Furthermore, the findings of the detrimental effects of taxes on investment and growth fail to account for the differences between developing and developed countries in which the institutional settings might alter the dynamics. (James 2009) It is therefore paramount to look at the effects in developing countries alone as this paper does.

Looking at tax incentives specifically and their effects on developing countries, empirical work is largely build on case study methodology, as it is hard to find a good way to quantify and compare tax incentives across countries. While anecdotal evidence from well-known cases like Malaysia, Ireland and Mauritius tells a story of success at gaining investment and growth from tax incentives (Bolnick 2004; Wells et al. 2001), other case studies find that incentives are largely redundant and does not lead to higher growth. Examples of these are the studies such as Reside (2006) on the Philippines and Canh et al. (2013) on Vietnam. The case studies therefore point in different directions on the matter of the effects of tax incentives.

Cross-country studies on tax incentives are rare and often regionally focused. (Parys and James 2010a) use a dif-in-dif design to look at the effect of tourism sector incentives in the Caribbean, and found a very large effect, in contrast to their study Parys and James (2010b) that looked at 14 countries in sub-Saharan Africa over 12 years. In the 
study of sub-saharan Africa, they found no robust relationship with any investment incentive variables and fixed capital formation, a measure for overall private investment. On FDI, they find a positive effect of tax holidays within the exporting sector, but not tax holidays in general. A. Klemm and Parys (2011) have conducted the largest cross-country study on the effect of tax incentives. They study how corporate tax rates, tax credits and tax holidays affected FDI in 47 Latin American, Caribbean, and African countries during 1985 - 2004 and conclude that tax incentives can be effective in attracting FDI but does not have an effect in increasing gross capital formation, indicating that it might not be beneficial for real economic growth.

Overall, the studies of the effect of tax incentives in developing countries offer contrasting conclusions, is often limited to single countries or regions and is based on relatively old data. This paper therefore presents an empirical analysis encompassing the largest number of countries over the longest time period, and presents updated data for the last decade.

On the issue of cost of tax incentives, studies have approached this in various ways. One important framework for evaluating the cost is the concept of the redundancy rate: how many investors who received the benefit would have invested anyway? (Wells et al. 2001) Survey evidence from different developing countries suggest that this ratio can be as high as 50 to 98 percent. (Johnson and Toledano 2013) One framework for evaluating the effectiveness of these policies is then to look at the relative relationship between the redundant investments and incremental investments. (Wells et al. 2001) This paper makes a different argument, as even if the redundancy rate is low, as long as it is not 0 , it still means there is an absolute cost to government revenue. As public funds can have a larger social value than private funds, the overall effects of these policies need to be taken into account. (IMF et al. 2015)

\section{Data collection}

The analysis in this paper builds upon a panel data set of 51 developing countries from 1985 to 2014. It consists of macroeconomic data gathered from the World Bank as well as data on tax incentives and tax rates, gathered by reading of auditing firm reports on the corporate tax system. The population of the analysis is in principle all developing countries. The sample of countries is the same as A. Klemm and Parys (2011), henceforth KVP, which consists of the African, Latin American and Caribbean countries for which tax incentive data from $\mathrm{PwC}$ was available for a majority of years for 1985-2004. I also use their data on five countries that were not included in the analysis of their paper, but which is coded in the same way. I furthermore extend the sample by adding some Asian countries. Since data for these countries is only available for very few years, however, this is not included in the regression analysis but only for some of the descriptive graphs. The sample is illustrated in Figure 1 and listed in the appendix.

The data is coded from reading the PwC Worldwide Tax Guides, noting the statutory corporate income tax rate for the most profitable firms, as well as the longest available tax holiday defined as a full elimination of taxes for a number of years. For both factors 
the analysis is extended only to the manufacturing sector. As PwC reports from 20052009 are not available, I have used the Worldwide Corporate Tax Guides from EY. While it would have been optimal to use the same source for all years 1985-2014, using the EY reports means that we avoid having a gap of missing data in the panel. However, this means that there is a risk of underreporting tax holidays since the information on tax incentives is not as detailed in the EY reports.

Figure 1:

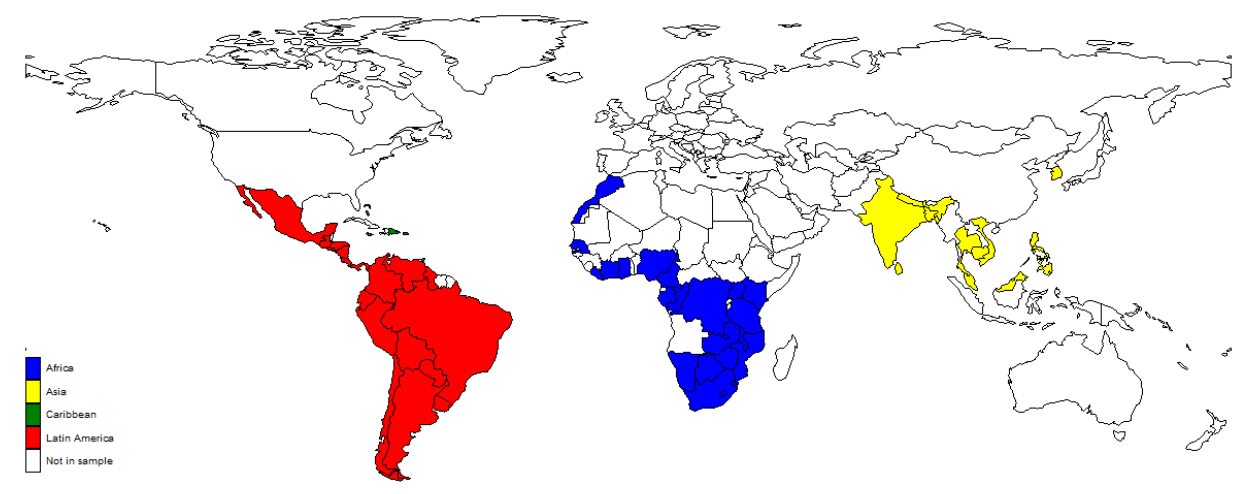

\section{Data analysis}

\subsection{Tax policy changes}

The dataset compiled enables me to look at the evolution and trends in tax policies over the last 30 years in the developing world.

Figure 2 describes the evolution in statutory corporate tax rates. The figure shows that there are differences between regions regarding the average level, with Africa having overall the highest tax rates and the Caribbean having much lower average tax rates. However, the average corporate tax rate is seemingly in free fall. This tendency is present in all regions (though Asia does not have a lot of data) and the average CIT rate over the sample has fallen from 38 percent in the 1980's to only around 26 percent today (excluding Asia). This is consistent with the development in other regions such as the EU. (Budiantoro 2015)

Figure 3 shows the evolution over the sample period in the use of tax holidays.Tax holidays have experienced a revival since the financial crisis in 2008 and have become increasingly popular. To correct for missing data problems, the graph is constructed as measured by percentage of sample with a tax holiday. Notably, this does not include the countries with a 0 pct. tax rate. Dividing the figure up by regions shows that the tendency of an increasing use of tax holidays is not driven by just one region - while there are differences in level between regions, the increase within the last 5 years of the sample seems to be a tendency throughout the developing world.

Last I look at the trends with respect to the length of tax holidays offered. Figure 4 
Figure 2:

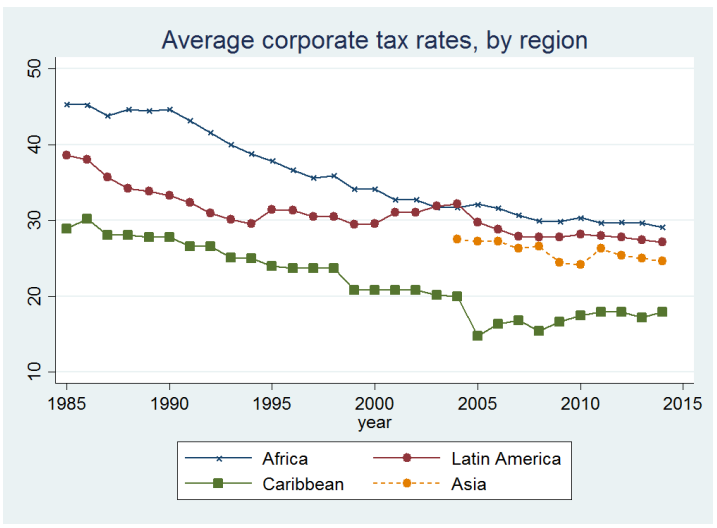

Figure 4:

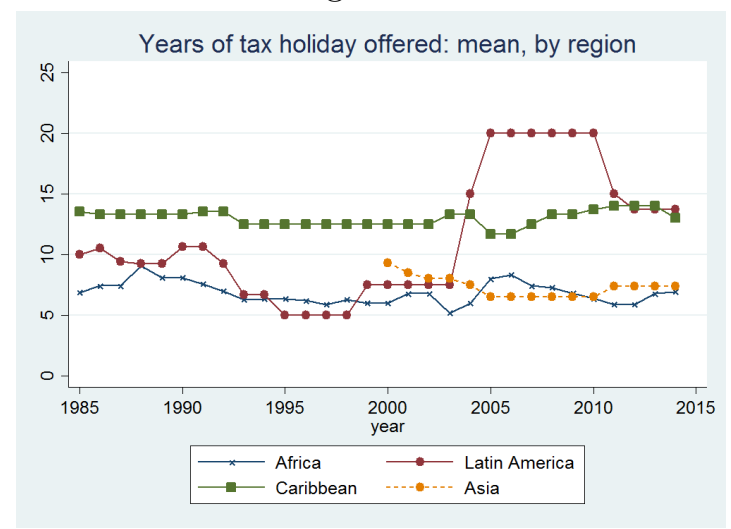

Figure 3:

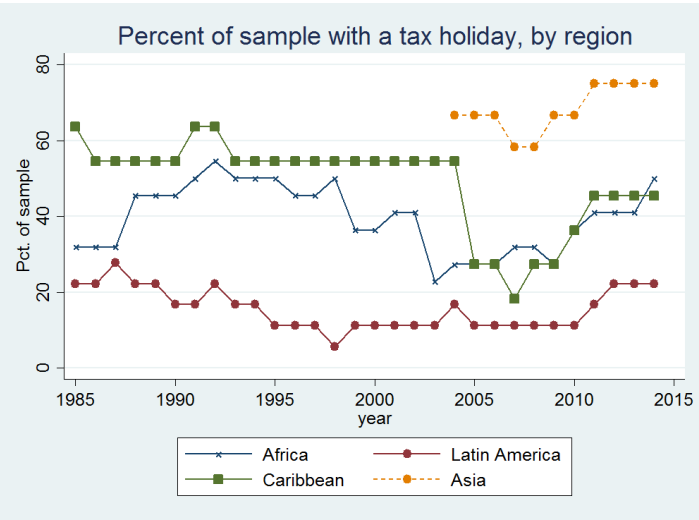

Figure 5:

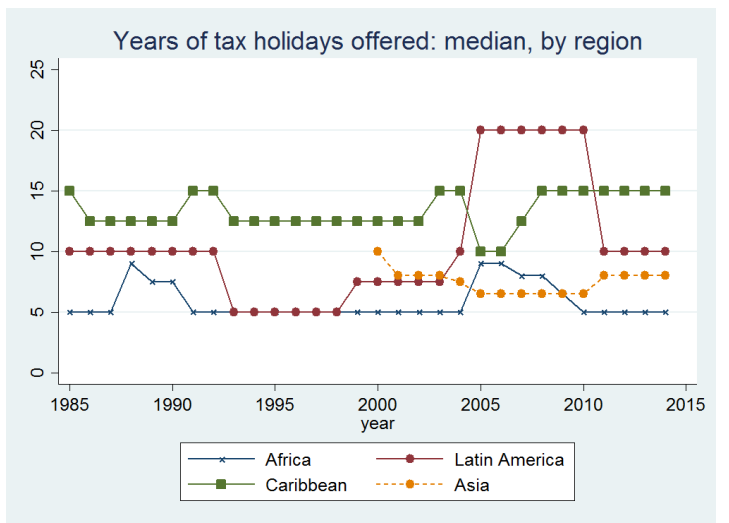

and 5 illustrate the average length of the tax holidays offered, ie. excluding the countries without a tax holiday. A simple average should be interpreted with some caution, as it is between a small number of countries and affected a lot by outliers, such as the tax holiday of 30 years in Columbia. Therefore both the mean and median is reported. The figure shows that the typical length of a tax holiday is around 10 years, up from much shorter offers in the 1990's. Even though the mean is currently on a downward trend, it is noteworthy that the length offered has returned to the high levels of the 1980's.

Overall, these findings indicate a trend across all four regions of an increasing policy focus on favorable tax conditions for firms, including lower rates as well as tax holidays.

\subsection{Regression analysis}

As the data shows, there is a large increase in the use of tax incentives: tax rates are decreasing, and tax holidays are being used more frequently. This only increases the need for a critical evaluation of their impacts on developing countries. In the next section, I turn to estimating the impact of tax holidays and decreasing tax rates on different 
indicators of economic and social development outcomes.

I estimate a dynamic panel model with fixed effects and a lagged dependent variable.

$$
V A R_{i, t}=\alpha+\delta V A R_{i, t-1}+\beta T A X_{i, t-1}+\lambda X_{i, t-1}+\gamma_{i}+\eta_{t}+\epsilon_{i, t}
$$

$\mathrm{X}$ represents a vector of control variables. These are key economic figures describing the overall welfare, openness and stability of the economies, as these are likely to affect both investment and human development outcomes. The inflation rate is used to control for the stability of the economy, and GDP and GDP per capita measures are used as a proxy for overall welfare and market size. For trade openness I use the sum of exports and imports of goods and services measured as a share of gross domestic product. A control variable is also added for the level of democracy, as research points to democratic institutions possibly being important for economic development (see eg. Li (2006) and Acemoglu et al. (2014)), as well as impacting whether tax incentives work (James 2009). This indicator is level of democracy from Freedomhouse on a scale of 1 to 10. (Dahlberg et al. 2017) Furthermore, it is conceivable that investment from abroad is less affected by policies in countries with a large extractive sector. I include a variable describing oil rents, which measures the net income from oil production as a percentage of GDP to control for natural resources to some degree, although it would have been optimal to have data for the overall size of natural resources. The independent variables are lagged by one period, because it is likely that the effect of the policy takes place with a lag, since investments take time planning and executing. It is therefore likely that not only tax policies but also the other economic indicators will be effective on next years investments rather than this year.

Including fixed effects on the country level controls for unobserved variables that are constant to the country over time, while the year fixed effects controls for shocks that are year specific but equal across countries. The lagged dependent variable is included to avoid endogeneity that can be caused by policy decisions being made based upon current level of the dependent variable, for example investment. Furthermore, adding the lagged dependent variable decreases serial correlation in the residuals. As is well known, including both a lagged dependent variable and fixed effects introduces a bias into the model. (Angrist and Pischke 2008) However, the bias decreases with $1 / \mathrm{T}$, and as the dataset covers a relatively long time period, the bias is not of concern.

The analysis is split into three parts. The first part focuses on the economic impacts and looks at the dependent variables FDI, private investment (gross fixed capital formation), GDP growth and total factor productivity growth. The second part focuses on public finance, and looks at government revenue, government spending, as well as specific spending on education and health. The third part looks at development outcomes: health and poverty amongst children measured by child anemia and child mortality, and enrollment rates in primary school. 


\subsubsection{Economic outcomes}

The first regressions I run are on net FDI inflows, private investment as measured by gross fixed capital formation and GDP growth. First of all, I am interested in the effect on FDI, as this is the intended effect of the tax incentives. However, it might be that through round tripping or crowding out, FDI increases but domestic investment decreases. Therefore, I would also like to look at the effect of actual aggregated investment in the economy, not just foreign. For this I use the indicator of gross private capital formation. The difference between them is that FDI also includes mergers and acquisitions, whereas gross private capital formation measures actual growth in the capital stock; which is assumed to be the point of tax incentives as well as more important for growth. Lastly, I also look on the effect on aggregate growth in the economy and productivity growth. 


\begin{tabular}{|c|c|c|c|c|}
\hline \multicolumn{5}{|c|}{ Regression: Economic outcomes } \\
\hline \multirow{2}{*}{\multicolumn{2}{|c|}{$\begin{array}{c}\text { FDI } \\
0.603^{* * *} \\
(0.095)\end{array}$}} & \multirow{2}{*}{$\begin{array}{c}\begin{array}{l}\text { Private In- } \\
\text { vestment }\end{array} \\
0.666^{* * *} \\
(0.041)\end{array}$} & \multicolumn{2}{|c|}{ GDP_growth TFP } \\
\hline & & & $\begin{array}{c}0.243^{* * *} \\
(0.066)\end{array}$ & $\begin{array}{c}0.884^{* * *} \\
(0.020)\end{array}$ \\
\hline Tax rate & $\begin{array}{c}-0.029^{*} \\
(0.017)\end{array}$ & $\begin{array}{c}0.024 \\
(0.019)\end{array}$ & $\begin{array}{c}0.003 \\
(0.042)\end{array}$ & $\begin{array}{l}-0.000 \\
(0.000)\end{array}$ \\
\hline Tax holiday & $\begin{array}{l}0.442^{*} \\
(0.256)\end{array}$ & $\begin{array}{l}-0.427 \\
(0.355)\end{array}$ & $\begin{array}{l}-0.023 \\
(0.429)\end{array}$ & $\begin{array}{l}-0.001 \\
(0.005)\end{array}$ \\
\hline Inflation & $\begin{array}{c}0.000 \\
(0.000)\end{array}$ & $\begin{array}{l}-0.000 \\
(0.000)\end{array}$ & $\begin{array}{l}-0.000 \\
(0.000)\end{array}$ & $\begin{array}{l}-0.000 \\
(0.000)\end{array}$ \\
\hline GDP & $\begin{array}{c}1.427 \\
(2.542)\end{array}$ & $\begin{array}{c}5.060^{* * *} \\
(1.771)\end{array}$ & $\begin{array}{c}1.385 \\
(2.551)\end{array}$ & $\begin{array}{l}-0.003 \\
(0.073)\end{array}$ \\
\hline GDP per cap. & $\begin{array}{l}-1.218 \\
(2.182)\end{array}$ & $\begin{array}{c}-3.954^{* *} \\
(1.741)\end{array}$ & $\begin{array}{c}-7.319^{* *} \\
(2.756)\end{array}$ & $\begin{array}{c}0.021 \\
(0.084)\end{array}$ \\
\hline Openness & $\begin{array}{c}0.004 \\
(0.009)\end{array}$ & $\begin{array}{c}0.014 \\
(0.011)\end{array}$ & $\begin{array}{c}0.045^{* * *} \\
(0.012)\end{array}$ & $\begin{array}{c}0.000 \\
(0.000)\end{array}$ \\
\hline Oilrents & $\begin{array}{c}-0.008 \\
(0.044)\end{array}$ & $\begin{array}{l}0.079^{*} \\
(0.045)\end{array}$ & $\begin{array}{l}-0.022 \\
(0.078)\end{array}$ & $\begin{array}{c}-0.002 \\
(0.002)\end{array}$ \\
\hline Democracy & $\begin{array}{c}-0.009 \\
(0.092)\end{array}$ & $\begin{array}{c}0.168 \\
(0.153)\end{array}$ & $\begin{array}{c}0.287 \\
(0.177)\end{array}$ & $\begin{array}{l}-0.002 \\
(0.002)\end{array}$ \\
\hline _cons & $\begin{array}{c}6.961 \\
(10.781)\end{array}$ & $\begin{array}{l}19.846^{*} \\
(9.932)\end{array}$ & $\begin{array}{c}52.869^{* * *} \\
(15.406)\end{array}$ & $\begin{array}{l}-0.063 \\
(0.487)\end{array}$ \\
\hline Obs. & 1099 & 1082 & 1108 & 723 \\
\hline YearFE & Yes & Yes & Yes & Yes \\
\hline CountryFE & Yes & Yes & Yes & Yes \\
\hline \multicolumn{5}{|c|}{$\begin{array}{c}\text { Standard errors in parentheses are clustered by country } \\
\text { and robust to heteroskedasticity }\end{array}$} \\
\hline \multicolumn{5}{|c|}{$\begin{array}{l}\text { Outliers not included for FDI: Liberia and Cayman Islands. } \\
\text { Liberia also not included for GDP growth. } \\
\quad{ }^{*} \mathrm{p}<0.10,{ }^{* *} \mathrm{p}<0.05,{ }^{* *} \mathrm{p}<0.010\end{array}$} \\
\hline
\end{tabular}

Regressing tax policies on FDI yields statistically significant results in the direction that would be theoretically expected: lower effective tax rate on an investment increases FDI. The magnitude of the effect indicates that a 10 percentage point increase in the corporate tax rate correlates with a 0,3 percentage point decrease in FDI in terms of GDP. This effect is relatively small, as it corresponds to around 6 percent of the mean and 1 percent of the standard deviation of FDI. Implementing a tax holiday correlates with a half percentage point increase in FDI in terms of GDP. This corresponds to 10 percent of the mean, 3 percent of the standard deviation, so the magnitude of this effect is on a level that is not inconsequential; however the overall attractiveness of course depends on the quality of FDI and on the cost of that tax holiday which is likely large. 
Regressing the tax policies on private investment is therefore what matters to our understanding of the actual effects of the tax incentives. Here, there are no significant effects of neither changing the tax rate nor implementing a tax holiday. This implies that while overall FDI might increase as an effect of tax incentives, the level of capital in the economy is not affected. This is in line with the results of the literature, specifically Klemm and Parys (2011). This means that the correlation with FDI must either be the part of FDI not included in gross fixed capital formation, or the increase in FDI must crowd out enough domestic investment to have no net effect. This might be the case that the type of investment most likely to be affected by tax incentives - the exportoriented, price-sensitive footloose investments - usually invest in ways that do not affect the capital stock, for example through mergers and acquisitions. It might also be that domestic firms are employing "round-tripping" strategies in which they set up foreign subsidiaries to do the investment domestically to qualify for the tax holiday. This would explain an increase in FDI without an accompanying increase in overall investment.

Furthermore, there are no significant results when looking at the correlation with GDP growth and total factor productivity growth. The first implies that the policies are not effective in attracting the kinds of investment that are creating jobs and growth. The latter implies that the kinds of investment that is attracted is not the kinds of FDI that are associated with the benefits of technology and knowledge transfer, and therefore does not yield effects on productivity gains. 


\begin{tabular}{|c|c|c|c|c|}
\hline \multicolumn{5}{|c|}{ Regression: Economic outcomes, last 10 years } \\
\hline & FDI & $\begin{array}{l}\text { Private in- } \\
\text { vestment }\end{array}$ & $\begin{array}{l}\text { GDP } \\
\text { growth }\end{array}$ & TFP \\
\hline LDV & $\begin{array}{c}0.553^{* * *} \\
(0.162)\end{array}$ & $\begin{array}{c}0.664^{* * *} \\
(0.079)\end{array}$ & $\begin{array}{c}0.181^{* * *} \\
(0.061)\end{array}$ & $\begin{array}{c}0.342^{* * *} \\
(0.087)\end{array}$ \\
\hline Taxrate & $\begin{array}{c}0.006 \\
(0.105)\end{array}$ & $\begin{array}{c}0.022 \\
(0.066)\end{array}$ & $\begin{array}{l}-0.076 \\
(0.079)\end{array}$ & $\begin{array}{c}0.001 \\
(0.001)\end{array}$ \\
\hline Tax holiday & $\begin{array}{c}-1.517^{* *} \\
(0.706)\end{array}$ & $\begin{array}{l}-0.720 \\
(0.683)\end{array}$ & $\begin{array}{c}0.563 \\
(0.682)\end{array}$ & $\begin{array}{l}-0.038 \\
(0.056)\end{array}$ \\
\hline Inflation & $\begin{array}{c}0.008 \\
(0.007)\end{array}$ & $\begin{array}{c}0.024 \\
(0.028)\end{array}$ & $\begin{array}{l}-0.004 \\
(0.019)\end{array}$ & $\begin{array}{l}0.001^{*} \\
(0.000)\end{array}$ \\
\hline GDP & $\begin{array}{c}24.495^{* *} \\
(9.956)\end{array}$ & $\begin{array}{l}18.606^{*} \\
(10.187)\end{array}$ & $\begin{array}{l}13.087 \\
(7.925)\end{array}$ & $\begin{array}{c}0.236 \\
(0.273)\end{array}$ \\
\hline GDP per cap. & $\begin{array}{c}-21.389^{* *} \\
(10.202)\end{array}$ & $\begin{array}{l}-19.048^{*} \\
(10.700)\end{array}$ & $\begin{array}{c}-31.934^{* * *} \\
(9.668)\end{array}$ & $\begin{array}{l}-0.079 \\
(0.222)\end{array}$ \\
\hline Openness & $\begin{array}{c}0.025 \\
(0.023)\end{array}$ & $\begin{array}{c}0.059^{* * *} \\
(0.015)\end{array}$ & $\begin{array}{c}0.031 \\
(0.025)\end{array}$ & $\begin{array}{l}-0.000 \\
(0.000)\end{array}$ \\
\hline Oilrents & $\begin{array}{c}0.014 \\
(0.088)\end{array}$ & $\begin{array}{l}-0.009 \\
(0.076)\end{array}$ & $\begin{array}{c}0.041 \\
(0.059)\end{array}$ & $\begin{array}{l}-0.000 \\
(0.001)\end{array}$ \\
\hline Democracy & $\begin{array}{c}0.011 \\
(0.289)\end{array}$ & $\begin{array}{c}0.269 \\
(0.429)\end{array}$ & $\begin{array}{l}1.219 * * \\
(0.582)\end{array}$ & $\begin{array}{l}0.022^{*} \\
(0.012)\end{array}$ \\
\hline Constant & $\begin{array}{l}90.196^{*} \\
(52.028)\end{array}$ & $\begin{array}{c}91.158 \\
(57.580)\end{array}$ & $\begin{array}{c}207.664^{* * *} \\
(55.980)\end{array}$ & $\begin{array}{l}-0.033 \\
(0.988)\end{array}$ \\
\hline Obs. & 375 & 368 & 375 & 198 \\
\hline YearFE & Yes & Yes & Yes & Yes \\
\hline CountryFE & Yes & Yes & Yes & Yes \\
\hline \multicolumn{5}{|c|}{$\begin{array}{c}\text { Standard errors in parentheses are clustered by country } \\
\text { and robust to heteroskedasticity }\end{array}$} \\
\hline \multicolumn{5}{|c|}{$\begin{array}{l}\text { Outliers not included for FDI: Liberia and Cayman Islands. } \\
\text { Liberia also not included for GDP growth. } \\
\qquad{ }^{*} \mathrm{p}<0.10,{ }^{* *} \mathrm{p}<0.05,{ }^{* *} \mathrm{p}<0.010\end{array}$} \\
\hline
\end{tabular}

Over the last decade, significant changes have happened to global capital flows. Investment into developing countries have increased, capital controls have decreased, and finance is becoming more globalized. Therefore it is interesting to observe how the effects of these policies look in this changing environment. Furthermore the data from the last decade is new data on tax incentives. The regression is done in a restriction of the sample to 2005-2014, i.e. the last decade for which the data is new. In the restricted analysis, there is no statistically significant effect of increasing tax rates. The regression on FDI shows that implementing a tax holiday has actually had a negative effect on FDI, statistically significant at the 95 pct. confidence level. The magnitude of the parameter, 
a 1,5 percentage point decrease in net FDI flows in pct. of GDP, corresponds to 25 pct. of the mean and 7,4 pct. of the standard deviation. It is therefore a relatively large decrease. There is no statistically significant correlation between the tax holiday and private investment. It thereby seems that countries that have implemented tax holidays in the last decade have not had a successful experience with this when it comes to attracting investment. Regarding GDP and total factor productivity (TFP) growth, tax incentives are again not significantly correlated.

As these results indicate a changing effect over time of the use of tax incentives, I explore this further by splitting the samples into three decades. Figure 6 shows the coefficients from the regressions: the blue line indicates the coefficient of tax holiday on FDI from the regression over the whole 30-year period, of 0,442. The shorter lines indicate the coefficient that is obtained when running the regression only on the restricted sample of 10 years at a time. What we find is that the coefficient is even larger in the first decade of the sample 1985-1994 (and statistically significant), then becomes 0 for the 1995-2004 period and becomes negative for the last decade, indicating that while the average effect is positive, it has been decreasing over the time period analyzed. This is relevant as it underlines the paradox that more and more countries have introduced tax holidays over that same time period.

Figure 6:

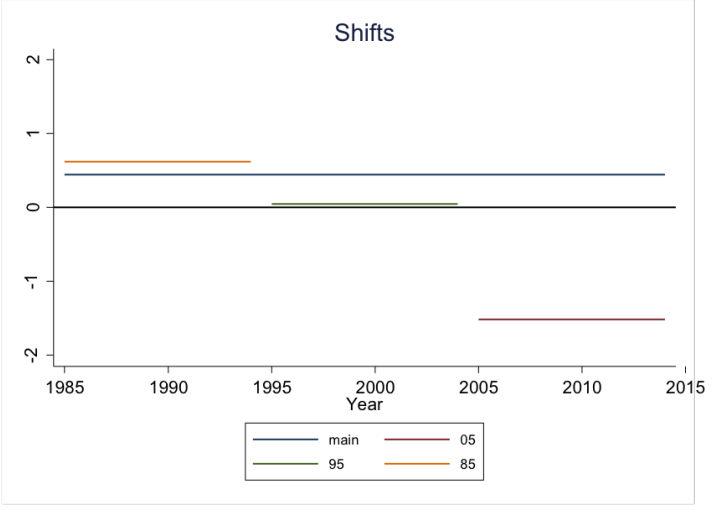

\section{Figure 7:}

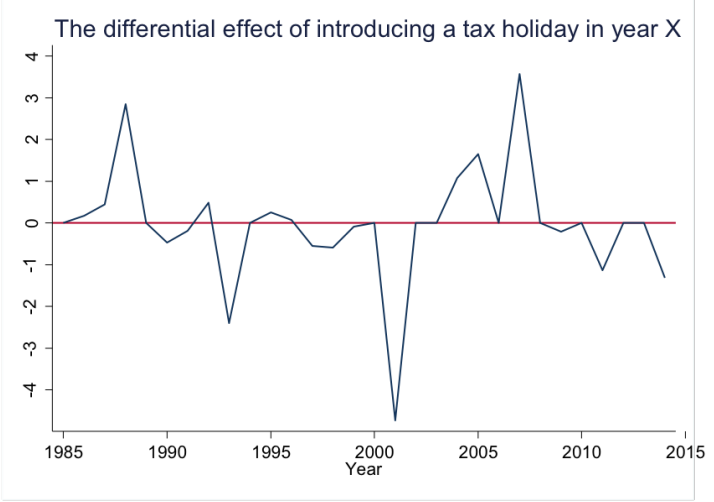

To explore this changing dynamic further, I run the main regression again over the whole sample, while introducing an interaction term for each year, which is equal to 1 if a country introduces a tax holiday in that year and 0 otherwise, in 30 different regressions to obtain the differential effect for each year.

$$
V A R_{i t}=\alpha+\delta V A R_{i, t-1}+\beta T A X_{i, t-1}+\omega(T H * Y e a r)_{i, t}+\lambda X_{i, t-1}+\gamma_{i}+\eta_{t}+\epsilon_{i, t}
$$

The result of the $\omega$ coefficients obtained for each regression for this interaction term is shown in figure 7 . While there is a clear pattern that the differential effect has become 
negative within the last decade, it seems that for the first 20 years of the sample there are a lot of fluctuation, rather than a clear time trend. It seems that there could be some business cycle trends going on, as the coefficient for example becomes negative around the Asian financial crisis, the Dotcom crisis and during the recent Great Recession. This indicates that overall, other factors in the global economy are what determine FDI flows more so than tax incentives.

\subsubsection{Public finance}

Secondly, I test the regression results of tax policies on public finances of a country: revenue, total spending as well as government spending on education and health. This is important because tax incentives can be extremely expensive and therefore put the public finances under pressure. This furthermore deteriorates the policy options of developing countries. 


\begin{tabular}{|c|c|c|c|c|}
\hline \multicolumn{5}{|c|}{ Regression: Public finance } \\
\hline & Revenue & Spending & $\begin{array}{l}\text { Education } \\
\text { exp. }\end{array}$ & Health exp. \\
\hline LDV & $\begin{array}{c}0.566^{* * *} \\
(0.040)\end{array}$ & $\begin{array}{c}0.763^{* * *} \\
(0.041)\end{array}$ & $\begin{array}{c}0.697^{* * *} \\
(0.066)\end{array}$ & $\begin{array}{c}0.753^{* * *} \\
(0.034)\end{array}$ \\
\hline Tax rate & $\begin{array}{c}0.015 \\
(0.015)\end{array}$ & $\begin{array}{l}-0.002 \\
(0.010)\end{array}$ & $\begin{array}{c}0.004 \\
(0.010)\end{array}$ & $\begin{array}{c}-0.013^{*} \\
(0.007)\end{array}$ \\
\hline Tax holiday & $\begin{array}{c}-0.731^{* *} \\
(0.289)\end{array}$ & $\begin{array}{l}-0.007 \\
(0.204)\end{array}$ & $\begin{array}{c}-0.200^{*} \\
(0.102)\end{array}$ & $\begin{array}{l}-0.009 \\
(0.090)\end{array}$ \\
\hline Inflation & $\begin{array}{c}0.000 \\
(0.000)\end{array}$ & $\begin{array}{c}-0.000^{* *} \\
(0.000)\end{array}$ & $\begin{array}{c}-0.000^{* * *} \\
(0.000)\end{array}$ & $\begin{array}{c}0.000 \\
(0.000)\end{array}$ \\
\hline GDP & $\begin{array}{l}-2.460 \\
(1.734)\end{array}$ & $\begin{array}{c}-0.533 \\
(1.341)\end{array}$ & $\begin{array}{l}-0.349 \\
(0.646)\end{array}$ & $\begin{array}{l}-0.097 \\
(0.635)\end{array}$ \\
\hline GDP per cap. & $\begin{array}{c}1.718 \\
(1.813)\end{array}$ & $\begin{array}{c}1.763 \\
(1.191)\end{array}$ & $\begin{array}{c}1.208 \\
(0.773)\end{array}$ & $\begin{array}{c}0.106 \\
(0.592)\end{array}$ \\
\hline Openness & $\begin{array}{c}0.007 \\
(0.007)\end{array}$ & $\begin{array}{l}-0.005 \\
(0.007)\end{array}$ & $\begin{array}{c}-0.005^{*} \\
(0.003)\end{array}$ & $\begin{array}{c}0.002 \\
(0.002)\end{array}$ \\
\hline Oilrents & $\begin{array}{c}0.062^{* *} \\
(0.027)\end{array}$ & $\begin{array}{c}0.071 \\
(0.043)\end{array}$ & $\begin{array}{c}0.023 \\
(0.031)\end{array}$ & $\begin{array}{c}0.005 \\
(0.006)\end{array}$ \\
\hline Democracy & $\begin{array}{l}-0.041 \\
(0.070)\end{array}$ & $\begin{array}{l}-0.083 \\
(0.075)\end{array}$ & $\begin{array}{l}0.087^{*} \\
(0.044)\end{array}$ & $\begin{array}{l}-0.003 \\
(0.024)\end{array}$ \\
\hline Constant & $\begin{array}{l}-0.959 \\
(9.400)\end{array}$ & $\begin{array}{l}-8.126 \\
(6.236)\end{array}$ & $\begin{array}{l}-7.471 \\
(4.675)\end{array}$ & $\begin{array}{c}0.405 \\
(3.009)\end{array}$ \\
\hline Obs. & 589 & 1065 & 372 & 732 \\
\hline YearFE & Yes & Yes & Yes & Yes \\
\hline CountryFE & Yes & Yes & Yes & Yes \\
\hline S & $\begin{array}{r}\mathrm{LDV}= \\
\text { lard errors in } \\
\text { and ro } \\
* \mathrm{p}<0 .\end{array}$ & $\begin{array}{l}\text { ed dependen } \\
\text { rentheses are } \\
t \text { to heteroske } \\
* \mathrm{p}<0.05, * *\end{array}$ & $\begin{array}{l}\text { ariable. } \\
\text { istered by cou } \\
\text { sticity } \\
<0.010\end{array}$ & \\
\hline
\end{tabular}

I find that implementing a tax holiday has a statistically significant negative effect on revenues. The correlation indicates that introducing a tax holiday will decrease revenue by 0,7 percentage point in terms of percent of GDP. This corresponds to around 5 pct. of the mean and 11 pct. of the standard deviation of tax revenue. While this might not sound like a large difference statistically, it is worth noting that this is the budget relative to GDP. For a country with revenue of 15 pct. of GDP, losing more than half of a percentage point of this every year amounts to a 5 percent revenue loss every year. This cumulative effect is very large in economic terms, where 5 percent of revenue every year can mean a lot of difference if budgets are small and there are not a lot of alternative revenue sources available. This should not be interpreted as the total cost of the tax holiday, as revenue could be increased from other sources to compensate for an expensive tax holiday. Rather, the total cost might be larger still, indicated by the parameter for 
the lagged dependent variable.

What is analyzed here is the aggregate effect, i.e. after other changes have happened such as increases in other taxes. The results indicate that the revenue loss from tax holidays is not (fully) compensated for by other revenue sources, as tax holidays are negatively correlated with overall revenue.

The observed effect on decreasing revenues from having a tax holiday does not translate into a decrease in overall spending. It might be the case then that countries are able to hold spending stable because they increase debt (Puerto Rico might be an example of this (Greenberg and Ekins 2015)). If this is the case, then tax holidays pose a threat to the fiscal sustainability of developing countries that could be problematic in the longer run. The effect of holidays on debt is thus something that could be explored in further studies. However, it is clear that the negative effect on revenues found in this study as well as previous literature are grounds for concluding that tax holidays have harmful effects on public finances.

Introducing a tax holiday is furthermore correlated with a decrease of education expenditure of 0,2 percentage points in terms of pct. of GDP. It corresponds to around 4,5 pct. of the mean and 8 pct. of the standard deviation of education expenditure. This again is not that large in statistical terms, but it means that a country with an education spending of 4,4 pct. of GDP would cut 4,5 pct. of the education budget annually. This compounds to a large effect economically, especially when the potential effect on poverty and opportunities of just one extra year of schooling is considered. Since overall spending cuts are not the channel at work here, it might be that the decrease in education spending reflects changed preferences. If the preference of policy makers is to ensure investment in the hope of growth, before goals of poverty alleviation is worked on, then they might cut education spending to finance investment incentives. It is of course unclear what exactly the channels here are, and it is worth investigating these complex interactions further. However it is clear that countries that have implemented tax holidays have overall spent less on education, which in itself is a worrying sign for the prospects of sustainable development.

There is no significant correlation between having a tax holiday and spending on health. Raising the tax rate has a small negative correlation with health expenditure. The magnitude however is very small. It is worth noting that since the regression does not take into account the degree to which external partners provide health care, this might be the explanation for this result.

\subsubsection{Development outcomes}

If introducing a tax holiday deteriorates public finances, it might have real effects on actual outcomes when we look at indicators for human development. As the government expenditure on health was not correlated with having a tax holiday, it is not surprising that indicators of health such as child anemia and child mortality are also not found to be correlated with tax incentives (while there are some statistically significant results, it is of magnitudes that are completely negligible). However, the decrease in expenditure on education does seem to translate into real effects, as introducing a tax holiday is 
correlated with almost a full percentage point decrease in the net enrollment rate. It shows that the decreases in public spending on education is not counteracted by other sources of (private) funding. The correlation corresponds to around 1 percent of the mean and 6 percent of the standard deviation, so it is relatively small in statistical terms. However, when 57 million children worldwide lack access to education, all things are worth considering. The result shows that policies that may seem unrelated to the broader issues of development in fact have very real consequences for sustainable development.

\begin{tabular}{|c|c|c|c|}
\hline \multicolumn{4}{|c|}{ Regression: Development outcomes } \\
\hline & Enrollment & $\begin{array}{l}\text { Infant mor- } \\
\text { tality }\end{array}$ & Anemia \\
\hline LDV & $\begin{array}{c}0.969^{* * *} \\
(0.029)\end{array}$ & $\begin{array}{c}0.976^{* * *} \\
(0.008)\end{array}$ & $\begin{array}{c}0.999^{* * *} \\
(0.014)\end{array}$ \\
\hline Tax rate & $\begin{array}{c}-0.086^{* *} \\
(0.039)\end{array}$ & $\begin{array}{l}0.026^{* *} \\
(0.012)\end{array}$ & $\begin{array}{c}0.002 \\
(0.010)\end{array}$ \\
\hline Tax holiday & $\begin{array}{c}-0.915^{* *} \\
(0.422)\end{array}$ & $\begin{array}{c}0.109 \\
(0.278)\end{array}$ & $\begin{array}{c}-0.269^{*} \\
(0.143)\end{array}$ \\
\hline Inflation & $\begin{array}{c}0.000^{* * *} \\
(0.000)\end{array}$ & $\begin{array}{c}0.000 \\
(0.000)\end{array}$ & $\begin{array}{c}0.000 \\
(0.000)\end{array}$ \\
\hline GDP & $\begin{array}{l}-0.035 \\
(2.835)\end{array}$ & $\begin{array}{c}-4.822^{* * *} \\
(1.373)\end{array}$ & $\begin{array}{c}-4.308^{* * *} \\
(1.201)\end{array}$ \\
\hline GDP per cap. & $\begin{array}{l}-0.802 \\
(2.407)\end{array}$ & $\begin{array}{c}5.773^{* * *} \\
(1.285)\end{array}$ & $\begin{array}{c}4.504^{* * *} \\
(1.234)\end{array}$ \\
\hline Openness & $\begin{array}{l}-0.017 \\
(0.018)\end{array}$ & $\begin{array}{c}0.004 \\
(0.005)\end{array}$ & $\begin{array}{c}0.004 \\
(0.003)\end{array}$ \\
\hline Oilrents & $\begin{array}{c}0.021 \\
(0.050)\end{array}$ & $\begin{array}{c}0.004 \\
(0.024)\end{array}$ & $\begin{array}{c}0.001 \\
(0.007)\end{array}$ \\
\hline Democracy & $\begin{array}{c}0.130 \\
(0.188)\end{array}$ & $\begin{array}{l}-0.016 \\
(0.072)\end{array}$ & $\begin{array}{c}-0.095^{* *} \\
(0.042)\end{array}$ \\
\hline Constant & $\begin{array}{c}12.947 \\
(13.169) \\
\end{array}$ & $\begin{array}{c}-33.520^{* * *} \\
(6.602)\end{array}$ & $\begin{array}{c}-23.777^{* * * *} \\
(6.753)\end{array}$ \\
\hline Obs. & 493 & 1105 & 829 \\
\hline YearFE & Yes & Yes & Yes \\
\hline CountryFE & Yes & Yes & Yes \\
\hline $\begin{array}{r}\mathrm{LDV}= \\
\text { Standard errors } \mathrm{i} \\
\text { and } \mathrm{r} \\
* \mathrm{p}<0\end{array}$ & $\begin{array}{l}\text { agged depender } \\
\text { parentheses are } \\
\text { oust to heterosk } \\
0,{ }^{*} \mathrm{p}<0.05,{ }^{*}\end{array}$ & $\begin{array}{l}\text { variable. } \\
\text { clustered by count } \\
\text { dasticity } \\
\mathrm{p}<0.010\end{array}$ & \\
\hline
\end{tabular}

\section{Conclusion}

This paper adds new data and findings to the debate on taxes and development, investment and growth. It has been shown that the use of tax holidays have increased 
in the last decade across the developing world, and that the effects on development are uncertain at best and negative at worst, especially when public finances and effect on welfare investments such as school enrollment is taken into account.

The findings of this paper show that tax incentives are not an effective tool for developing countries to achieve sustainable development. The effect on FDI is small, and does not contribute to actual economic growth. The effect on public finances is negative, and thereby undercuts the ability of the government to steer its own road towards development. The effect on the broader objectives of development is negative, as evidenced by the negative correlation with the opportunities for children to go to school. In short, this paper concludes that tax incentives are more likely to undermine than facilitate growth and development, and urges countries to take steps towards phasing out these policies.

As these findings clearly show that tax holidays are not cost effective and possibly harmful, they raise the question of why countries continue to implement them as well as what could be positive policy steps for the future. The debate on tax incentives cannot be seen in isolation from the larger issue of tax competition or of lobbying from foreign multinationals. (James 2009; Zolt 2015) The dynamics of this competition and the motivations for implementing tax incentives should be on the agenda for future research. Research should also focus on ways to phase out these policies and decrease the pressures from tax competition, such as initiating a process of regime building among its neighboring countries, and working on mutual commitments against harmful tax competition. This could lead to increased transparency and introduce streamlined reporting and monitoring of all incentives, and possibly forming a UN tax body as has been proposed by G77. (Johnson and Toledano 2013; Eurodad 2016) Other actions that can be implemented unilaterally is to focus on infrastructure, institutions and education towards the goal of improving the investment climate, or to implement industrial policies that are narrower in scope such that they aim more directly at the intended aims. (James et al. 2010; Johnson and Toledano 2013)

\section{References}

Acemoglu, Daron et al. (2014). Democracy Does Cause Growth. NBER Working Paper 20004. National Bureau of Economic Research, Inc. URL: https://ideas . repec . $\mathrm{org} / \mathrm{p} / \mathrm{nbr} / \mathrm{nberwo} / 20004$.html (visited on 01/10/2017).

Agosin, Manuel R. and Roberto Machado (2005). "Foreign Investment in Developing Countries: Does it Crowd in Domestic Investment?" In: Oxford Development Studies 33.2, pp. 149-162. ISSN: 1360-0818. DOI: 10.1080/13600810500137749. URL: http: //dx.doi.org/10.1080/13600810500137749 (visited on 01/31/2017).

Alfaro, Laura and Jasmina Chauvin (2016). Foreign Direct Investment, Finance, and Economic Development. SSRN Scholarly Paper ID 2908440. Rochester, NY: Social Science Research Network. URL: https : / / papers . ssrn . com / abstract $=2908440$ (visited on 06/07/2017). 
Angrist, Joshua D. and Jörn-Steffen Pischke (2008). Mostly Harmless Econometrics: An Empiricist's Companion. Englisch. Princeton: Princeton University Press. ISBN: 978-0-691-12035-5.

Bolnick, Bruce (2004). Effectiveness and Economic Impact of Tax Incentives in the SADC Region. URL: http://pdf.usaid.gov/pdf_docs/Pnacy929.pdf.

Bösenberg, Simon, Peter Egger, and Benedikt Zoller-Rydzek (2017). "Capital taxation, investment, growth, and welfare". en. In: Int Tax Public Finance, pp. 1-52. IssN: 09275940, 1573-6970. DOI: 10.1007/s10797-017-9454-3. URL: https ://link. springer. com/article/10.1007/s10797-017-9454-3 (visited on 06/07/2017).

Budiantoro, Setyo (2015). Anticipating Tax War in the ASEAN Economic Integration Era. URL: http : / / foolsgold. international / wp-content/uploads / 2015 / 09 / ASEAN-tax-wars . pdf.

Canh, Nguyen Thi et al. (2013). "Measuring the Effectiveness of Corporate Income Tax Investment Incentives for Domestic Companies in Vietnam". In: Journal of Emerging Issues in Economics, Finance and Banking 1.1.

Cantwell, John and Ram Mudambi (2005). "MNE competence-creating subsidiary mandates". en. In: Strat. Mgmt. J. 26.12, pp. 1109-1128. ISSN: 1097-0266. DOI: 10.1002/ smj . 497. URL: http : / / onlinelibrary . wiley . com/doi / 10 . 1002 / smj . 497 / abstract.

Di John, Jonathan (2008). "Taxation, Resource Mobilisation, and Productive CapacityBuilding in LDC's". In: Study prepared for UNCTAD as a background paper for The Least Developed Countries Report 2009. URL: http://unctad.org/sections/ldc_ dir/docs/ldcr2009_dijohn_en.pdf.

Eurodad (2016). An Intergovernmental UN Tax Body - why we need it and how we can get it. URL: http: / /www . eurodad . org/Entries/view/1546626/2016/08/29/AnIntergovernmental - UN - Tax-Body-why - we-need-it - and-how-we-can-get-it (visited on 01/29/2017).

Fletcher, Kevin (2002). Tax incentives in Cambodia, Lao PDR and Vietnam. Hanoi, Vietnam. URL: https://www.imf .org/external/pubs/ft/seminar/2002/fdi/eng/ pdf/fletcher.pdf.

Forsgren, Mats (2008). Theories of the Multinational Firm: A Multidimensional Creature in the Global Economy. English. Cheltenham, Glos, UK; Northampton, MA: Edward Elgar Pub. ISBN: 978-1-84844-117-0.

IMF (2011). Revenue Mobilization in Developing Countries. URL: https ://www.imf . org/external/np/pp/eng/2011/030811.pdf.

IMF et al. (2015). Options for low income countries' effective and efficient use of tax incentives for investment : a report to the G-20 development working group by the $I M F, O E C D$, UN and World Bank. en. Tech. rep. 100756. The World Bank, pp. 143. URL: http : / / documents . worldbank .org/curated/en/794641468000901692/ Options-for-low-income-countries-effective-and-efficient-use-of-taxincentives-for-investment-a-report-to-the-G-20-development-workinggroup-by-the-IMF-OECD-UN-and-World-Bank (visited on 01/09/2017).

James, Sebastian (2009). Incentives and investments : evidence and policy implications. en. Tech. rep. 58816. The World Bank, pp. 1-50. URL: http://documents . worldbank. 
org/curated/en/945061468326374478/Incentives-and-investments-evidenceand-policy-implications (visited on 01/23/2017).

James, Sebastian et al. (2010). "Providing incentives for investment". In: Investment climate in practice 1, URL: https : / openknowledge . worldbank.org/bitstream/ handle / 10986/10511/540170BRI0Prov10Box345635B01PUBLIC1. pdf ? sequence $=1$ (visited on $01 / 27 / 2017$ ).

Johnson, Lise and Perrine Toledano (2013). Investment Incentives: The good, the bad and the ugly Assessing the costs, benefits and options for policy reform. URL: http://ccsi. columbia.edu/files/2014/01/VCC_conference_paper_-_Draft_Nov_12.pdf.

Klemm, Alexander and Stefan Van Parys (2011). "Empirical evidence on the effects of tax incentives". en. In: Int Tax Public Finance 19.3, pp. 393-423. IsSN: 0927-5940, 1573-6970. DOI: 10.1007/s10797-011-9194-8. URL: http://link. springer.com/ article/10.1007/s10797-011-9194-8 (visited on 08/03/2016).

Klemm, Mr Alexander, Dennis P. J. Botman, and Reza Baqir (2008). Investment Incentives and Effective Tax Rates in the Philippines: A Comparison with Neighboring Countries. en. Google-Books-ID: _iKUtfUfvR4C. International Monetary Fund. ISBN: 978-1-4519-1518-1.

Lee, Young and Roger Gordon (2005). "Tax structure and economic growth". In: Journal of Public Economics 89.5-6, pp. 1027-1043. ISSN: 0047-2727. URL: http: //econpapers . repec.org/article/eeepubeco/v_3a89_3ay_3a2005_3ai_3a5-6_3ap_3a10271043. htm.

Li, Quan (2006). "Democracy, Autocracy, and Tax Incentives to Foreign Direct Investors: A Cross-National Analysis". In: The Journal of Politics 68.1, pp. 62-74. ISSN: 00223816. DOI: $10.1111 / \mathrm{j} .1468-2508.2006 .00370$. x. URL: http://www . journals . uchicago . edu / doi / full / 10.1111/j.1468-2508.2006.00370.x (visited on 01/30/2017).

Lucas, Robert E. (1990). "Why Doesn't Capital Flow from Rich to Poor Countries?" In: The American Economic Review 80.2, pp. 92-96. ISSN: 0002-8282. URL: http: //www.jstor.org/stable/2006549 (visited on 07/26/2016).

Margalioth, Yoram Y. (2003). Tax Competition, Foreign Direct Investments and Growth: Using the Tax System to Promote Developing Countries. SSRN Scholarly Paper ID 462622. Rochester, NY: Social Science Research Network. URL: http://papers .ssrn. com/abstract $=462622$ (visited on $07 / 27 / 2016$ ).

Mooij, Ruud A. de and Sjef Ederveen (2003). "Taxation and Foreign Direct Investment: A Synthesis of Empirical Research". In: International Tax and Public Finance 10, pp. 673-93. URL: https://ideas.repec.org/p/ces/ceswps/_588.html (visited on 01/27/2017).

Parys, Stefan Van and Sebastian James (2010a). The Effectiveness of Tax Incentives in Attracting FDI: Evidence from the Tourism Sector in the Caribbean. Working Papers of Faculty of Economics and Business Administration, Ghent University, Belgium. Ghent University, Faculty of Economics and Business Administration. URL: http : //econpapers.repec.org/paper/rugrugwps/10_2f675.htm.

- (2010b). "The effectiveness of tax incentives in attracting investment: panel data evidence from the CFA Franc zone". en. In: Int Tax Public Finance 17.4, pp. 400-429. 
ISSN: 0927-5940, 1573-6970. DOI: 10.1007/s10797-010-9140-1. URL: http://link. springer.com/article/10.1007/s10797-010-9140-1 (visited on 01/27/2017).

Reside, Renato E. (2006). Towards Rational Fiscal Incentives (Good Investments or Wasted Gifts?) UP School of Economics Discussion Paper 200601. University of the Philippines School of Economics. URL: https://ideas.repec.org/p/phs/dpaper/ 200601.html (visited on 01/25/2017).

Stokey, Nancy L. and Sergio Rebelo (1995). "Growth Effects of Flat-Rate Taxes". In: Journal of Political Economy 103.3, pp. 519-550. ISSN: 0022-3808. URL: http://www. jstor.org/stable/2138697.

Tuomi, Krista (2012). Review of investment incentives: Best practice in attracting investment. Tech. rep. International Growth Centre. URL: http://www . theigc .org/wpcontent/uploads/2014/09/Tuomi-2012-Working-Paper .pdf.

Wells, Louis et al. (2001). Using Tax Incentives to compete for Foreign Investment: Are they worth the costs? URL: https://openknowledge . worldbank.org/bitstream/ handle/10986/13979/multiOpage . pdf? sequence=1\&isAllowed=y.

Zee, Howell H, Janet G Stotsky, and Eduardo Ley (2002). "Tax Incentives for Business Investment: A Primer for Policy Makers in Developing Countries". In: World Development 30.9, pp. 1497-1516. ISSN: 0305-750X. DOI: 10.1016/S0305-750X (02) 00050-5. URL: http://www.sciencedirect.com/science/article/pii/S0305750X02000505 (visited on $07 / 28 / 2016$ ).

Zolt, Eric (2015). Tax incentives: Protecting the tax base. Paper for workshop on Tax Incentives and Base Protection. New York: UN. 


\section{Appendix}

Table 1: Countries in sample

\begin{tabular}{|llll|}
\hline Latin America & Caribbean & Africa & Asia \\
\hline Argentina & Antigua and Barbuda & Botswana & Bangladesh \\
Bolivia & Bahamas & Côte d'Ivoire & India \\
Brazil & Bermuda & Cameroon & Cambodia \\
Chile & Barbados & Congo - Brazzaville & Korea \\
Colombia & Cayman Islands & Gabon & Sri Lanka \\
Costa Rica & Dominican Republic & Ghana & Maldives \\
Ecuador & Jamaica & Kenya & Malaysia \\
Guatemala & St. Lucia & Liberia & Nepal \\
Guyana & Puerto Rico & Morocco & Philippines \\
Honduras & Trinidad and Tobago & Mozambique & Thailand \\
Mexico & British Virgin Islands & Mauritius & Vietnam \\
Nicaragua & & Malawi & \\
Panama & & Namibia & \\
Peru & & Nigeria & \\
Paraguay & & Senegal & \\
El Salvador & & Swaziland & \\
Uruguay & & Tanzania & \\
Venezuela & & Uganda & \\
& & South Africa & \\
& & Congo - Kinshasa & \\
& & Zambia & \\
& & Zimbabwe & \\
& & & \\
& & &
\end{tabular}

Note: Asian countries are not included in regression analysis. 
Table 2: Dependent variables

\begin{tabular}{|c|c|c|c|c|c|c|c|}
\hline Variable & Unitv & Obs. & Mean & $\begin{array}{l}\text { Std. } \\
\text { dev. }\end{array}$ & Min & Max & Source \\
\hline FDI & $\begin{array}{l}\text { Net inflows in pct. of } \\
\text { GDP. }\end{array}$ & 1413 & 4,15 & 14,64 & $-82,89$ & 466,4 & $\begin{array}{l}\text { World } \\
\text { Bank }\end{array}$ \\
\hline $\begin{array}{l}\text { Private invest- } \\
\text { ment }\end{array}$ & $\begin{array}{l}\text { Gross fixed capital for- } \\
\text { mation in pct. of GDP }\end{array}$ & 1376 & 19,89 & 6,36 & 2,00 & 52,93 & $\begin{array}{l}\text { World } \\
\text { Bank }\end{array}$ \\
\hline GDP growth & Annual pct. growth & 1465 & 3,46 & 5,71 & $-51,03$ & 106,2 & $\begin{array}{l}\text { World } \\
\text { Bank }\end{array}$ \\
\hline TFP & Annual pct. growth & 891 & 0,56 & 0,26 & 0,12 & 3,07 & $\begin{array}{l}\text { Penn } \\
\text { world } \\
\text { tables } \\
\text { (Feenstra, } \\
\text { Inklaar, } \\
\text { and Tim- } \\
\text { mer 2015) }\end{array}$ \\
\hline Revenue & $\begin{array}{l}\text { Tax revenue in pct. of } \\
\text { GDP }\end{array}$ & 768 & 15,71 & 6,39 & 0,23 & 45,80 & $\begin{array}{l}\text { World } \\
\text { Bank }\end{array}$ \\
\hline Spending & $\begin{array}{l}\text { General government fi- } \\
\text { nal consumption expen- } \\
\text { diture in pct. of GDP }\end{array}$ & 1391 & 14,14 & 4,95 & 2,04 & 63,94 & $\begin{array}{l}\text { World } \\
\text { Bank }\end{array}$ \\
\hline $\begin{array}{l}\text { Education } \\
\text { expenditure }\end{array}$ & $\begin{array}{l}\text { General government ex- } \\
\text { penditure on education } \\
\text { as a percentage of GDP. }\end{array}$ & 628 & 4,39 & 2,46 & 0,72 & 44,33 & $\begin{array}{l}\text { World } \\
\text { Bank }\end{array}$ \\
\hline $\begin{array}{l}\text { Health expendi- } \\
\text { ture }\end{array}$ & $\begin{array}{l}\text { Public health expendi- } \\
\text { ture in pct. of GDP. }\end{array}$ & 932 & 2,96 & 1,35 & 0,05 & 7,37 & $\begin{array}{l}\text { World } \\
\text { Bank }\end{array}$ \\
\hline Enrollment & $\begin{array}{l}\text { Net enrollment rate pri- } \\
\text { mary school both sexes } \\
\text { in pct. }\end{array}$ & 754 & 84,28 & 14,74 & 35,09 & 100 & $\begin{array}{l}\text { World } \\
\text { Bank }\end{array}$ \\
\hline Infant mortality & $\begin{array}{l}\text { Mortality rate per } 1000 \\
\text { newborns }\end{array}$ & 1405 & 48,27 & 34,01 & 6,10 & 171,20 & $\begin{array}{l}\text { World } \\
\text { Bank }\end{array}$ \\
\hline Anemia & $\begin{array}{l}\text { Percentage of children } \\
\text { under age } 5 \text { whose } \\
\text { hemoglobin level is } \\
\text { under target. }\end{array}$ & 1034 & 47,70 & 19,18 & 17,80 & 85,10 & $\begin{array}{l}\text { World } \\
\text { Bank }\end{array}$ \\
\hline
\end{tabular}

